ISSN 2449-7479

eISSN 2543-8840

amme.wne.sggw.pl

Annals of Marketing Management \& Economics

Vol. 4, No 1, 2018, 89-99

DOI 10.22630/AMME.2018.4.1.7

\title{
ECONOMIC KNOWLEDGE AND AWARENESS AND THE COMPETENCE OF THE YOUNG GENERATION OF THE ŚWIĘTOKRZYSKIE VOIVODESHIP IN THE ACHIEVEMENT OF FINANCIAL STABILITY
}

\author{
Jarosław W. Przybytniowski \\ Jan Kochanowski University in Kielce, Poland
}

\section{INTRODUCTION}

China's wisdom proclaims this: "that money does not bring happiness, but we can cannot live without it". Economic Education that allows Fostering entrepreneurial mindsets awareness and competence in making the right decisions on product placement of their financial resources in today's globalised market enlarge, on one of the pillars of the knowledge necessary to achieve professional and personal satisfaction. This applies both to the young and older generation because - as he showed the last global crisis on the financial markets, (which caused a serious crisis of confidence in the financial sector) - lack of knowledge in this respect can we cost you.

The aim of this paper is to analyse the importance of the knowledge economy to build awareness and competence of the students in the management of finances in the current, constantly changing environment. Design development was subject to the hypothesis in accordance with that - there is a relationship between the level of the knowledge economy and the increase of awareness and competence of the younger generation in achieving financial stability and consequently their independence. Analysis studies were carried out on two planes: Theoretical and empirical. Theoretical analysis is based on the use of knowledge in the literature of both Polish and foreign policy. Empirical analysis used a presentation of the results of surveys carried out in 2016, among Academic Youth (study desktop and portable exams I and II), studying at the universities of the Świętokrzyskie, 
in the field of economic sciences, in discipline: economics, science management and finance, aged 20 to 30 years ${ }^{1}$ (target group), making possible assessment scale and projection of changes in the composition of economic awareness over the matter.

\section{DETERMINANTS OF ECONOMIC AWARENESS. THE CONCEPT AND THE NATURE OF ECONOMIC EDUCATION}

Whereas the earlier, copyright considerations on the importance of economic education to build awareness of the younger generation, taking financing decisions, can be defined "as the impact of economic determinants relating to get financial management by households such as: current expenditure, save, investment free resources for financial or insurance to" 2 . At this point, note that each man think of a better future and encountered some difficulties are transitional and as a result will be able to develop. Often it turns out that difficulties encountered turn out to be long-term and their solution does not appear in itself because that is and my personally we are the perpetrators of our problems because we cannot or do not have knowledge of how to solve. Be aware that the knowledge economy is like health - also from time to time our memory gets disease. Not to fall into the incurable disease, it is worth to spend more attention prophylaxis related to the improvement of our knowledge - in other words - develop in its proceedings the relevant set of rules that lead to a reduction of the risks associated with our ignorance. It can be seen as its own insurance policy in the event of difficulties arising, but it depends on each of us.

On the basis of previous studies, by author, "education economic, which will increase the awareness and the result and the development of our competence - educates positive habits that are necessary for the proper management of our financial management, whereas our needs in closer or further period. Successive exploration of the knowledge economy, results in recognizing the opportunities and threats associated with the functioning of the market, for customers will take the ever more aware of the economic decisions". If our success in life we will be able to define as achieving our financial stability and independence and will allow us to pursue our needs, we cannot decide to forgo economic education. None of us is born with knowledge. We need themselves gradually acquire in the course of our lives. Unfortunately, already at the stage of school teachers do not learn practical skills relating to issues of micro and macroeconomic policies. Low awareness and therefore the awareness of economic among young people entering into adult life, leads ultimately to deepen the social inequalities.

Economic education can be seen as a process by which the customers/investors improve your ability to understand the rules on the functioning of the market. With the addition of this knowledge, if necessary they may request the assistance of, shall informed choices, as well as take effective action to improve its financial prosperity and ensure its protection. Economic Education is not only addressed, or primarily to investors. It is an

\footnotetext{
${ }^{1}$ Tests were carried out in the provinces: małopolskie, podkarpackie and lubelskie. Total, together with the świetokrzyskie tested was 1,200 people. These studies are a continuation of the analyses carried out in a similar way in the years between 2012 and 2014.

${ }^{2}$ See the scientific studies of the years 2007-2017.
} 
essential part of the members of the households who each day shall take the relevant decisions - short-term and long-term, e.g. with a view of training children that about saving retirement [The Importance ..., 2006].

By author, economic education can be carried out on three key levels. These are: the knowledge economy and to understand it - the customer knows and understands the principles of the functioning of the market, skills and competences with knowledge of the economic - based on the customer possesses the knowledge and awareness of having an impact on the implementation of their own needs and awareness and responsibility - customers understand that taken by them decisions have an impact on the other.

By the above attributes economic education can say that to be effective there must be a relationship, i.e.: education needs to improve knowledge, thereby increasing the competence and obtained knowledge must lead to a change in customer behaviour (Implementation) needs by increasing awareness of economic (Fig. 1).

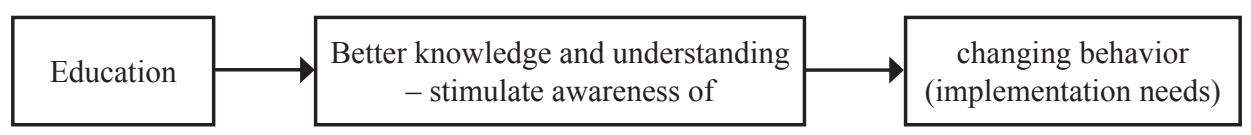

FIG. 1. Impact of education to change the behaviour of the financial

Source: the author.

Economic Education should be carried out as long as it brings effects in the form of an increase in awareness and competence and is not too expensive. With the growing importance of economic education should also have regard to the costs that it generates and how shall take into account the human motivations and capabilities of human perception [Chłoń-Domińczak et al. 2013] and ways to deal with stress in a dynamic market environment. Economic Education is to be troubleshooting low skills customers. At the same time constitute an integral part of the entire decision-making process in which are also important in other factors and mutual interactions between them. We can these include: the availability of reliable and accurate expert advice, offered options default financial products that bring benefits to the customer and not the seller, transparency and simplicity of financial products to ensure their comparability, the imposition of liability to the seller for sold unsuitable for customer financial product and restrictions on the sale of products particularly risky [Willis 2008].

As indicate $\mathrm{Xu}$ and Zia [2012] the level of the knowledge economy affects the degree of economic development of the country in which the person resides. It turns out that its level is higher among the population of developed countries. Similar conclusions are based on "national research Longitudional Survey of Youth" conducted by Lusardi, Mitchell, Curto [2010] among people aged 23-28 years.

In many countries of the world the measurement of the knowledge economy is based on the set of questions that cover the scope of three basic issues, i.e. how to calculate the percentage of inflation and risk diversification [Lusardi et al. 2010]. Shall be that for the understanding of the concept of saving the average customer should understand and be able to move in the area of these issues [Chłon-Domińczak et. al. 2013]. 
In the context of the problem of low economic knowledge it can be concluded that the society needs information and education and the existence of transparent and fixed rules on the functioning of the market, in its environment closer and further [Przybytniowski 2013]. Education in the functioning of the market, must be carried out on many planes, because only to increase knowledge and awareness and therefore the powers in respect of the implementation of its own needs and reasonableness educate [Przybytniowski 2007, Przybytniowski and Pacholarz 2015, Przybytniowski 2016, Grzebieniak 2016].

\section{AWARENESS AND ECONOMIC POWERS}

In view of the dynamic development of the financial markets, demographic change and economic subjects economic competence, including financial in recent years has particular significance. Change the needs of individuals as well as new and increasingly complex financial products and with them appears to have an adequate knowledge economy and skills to these needs in the best extent and as far to meet.

The issue of competence and awareness of economic, including financial is important because it does not concern only the individual units at micro, but includes the society as a whole and affects their mutual interactions that affect the economy [Pieńkowska-Kamieniecka 2016]. At the macroeconomic level, greater knowledge [Pacholarz 2016] and competence increase because the demand of household products and services, leading to the development of the market, reducing fluctuations in economic and acting accelerator growth (Fig. 2) [Jariwala and Sharma 2011].

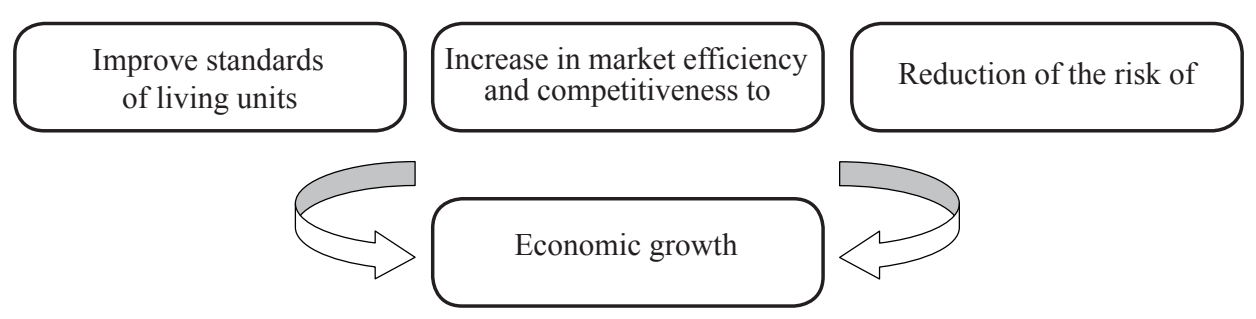

Fig. 2: Benefit from Economic Education

Source: the author based on Messy 2009.

Therefore, it can be concluded that the increase in awareness and competence of economic leads appropriate education and therefore to the situation in which blow away all market operators. On the other hand, incorrect decisions due to the lack of the knowledge economy, including financial lead to disadvantaged social and economic unit and the households, restricting the development of the market and leading to increased public expenditure on social benefits and other broad state aid associated with the commitments made by the citizens of the inadequacy of the financing decisions [Pieńkowska-Kamieniecka 2016]. There is a strong link between knowledge economy, financial exclusion and over-indebtedness. This relationship can be seen in two variants: pessimistic and optimistic. Worse may lead to low awareness of economic. The lack of a proper economic 
education leads to further reluctance in broadening knowledge in this field, which results in a lack of competence and of averseness to financial institutions. Persons with low awareness and therefore the knowledge economy, easier to become victims of financial exclusion. This leads to the use of other institutions (para-financial), which in a quick way to grant loans, but on worse conditions [Iwanicz-Drozdowska and Nowak 2011]. In the case of optimistic - high economic awareness gives you the ability to avoid unwanted problems associated with easier financial management. The educational program provides an opportunity for systematic deepening of the knowledge economy [Iwanicz-Drozdowska and Nowak 2011]. As we read in the development of Laboul [2012], the national strategy of economic education, including financial, has been defined as "coordinated approach at national level to economic education, including financial, which consists of a customized framework or program". Please note that the customer have the appropriate knowledge is aware of the larger the potential market. This translates too materially to the increased demand and hence on the more innovative products and services. In addition, it also affects the increase confidence in the institution of the financial market. Economic education should not be seen as the sole means of influencing the reduction of the asymmetry of information between service providers and recipients of services, but as a factor which ensures an adequate level of protection of customers and their needs and consequently the proper functioning of the market to give you the word in economic growth.

\section{RESEARCH METHODOLOGY}

In the development were used methods of analysis descriptive-qualitative comparative analysis and statistical analysis. For the collection of the material of the original author used the results of the survey conducted in 2016 and on the study of knowledge and awareness of economic. This questionnaire contains general part, including questions related to metric respondents and part of a detailed, relating to the assessment of the status of the subjective, objective and sources of knowledge and preferred forms of economic education students.

Made in the representations of Likert's scale, where the author obtains the answer associated with the acceptance of the phenomenon. The proposed scale consisted of the cafeteria, which connects five replies arranged on the total acceptance -5 , to total rejection -1 . Tested student was to determine to what extent agrees with the specified question where: 1 - meant "strongly small", 2 - meant "small", 3 - meant "medium", 4 - meant "high", 5 - meant "strongly high".

The selection of the sample provides the representativeness of the results for students aged from 18 years to 30 , in terms of gender and place of residence. The choice of this ensures the comparability of the results of earlier years, carried out within the framework of the statutes. In both cycles research, attempt consisted of 320 people, which made it possible to carry out analyses in more detailed. In this test was attended by students on desktop and portable exams I and II, universities with the Świętokrzyskie, studying in the field of economic sciences, in discipline: economics, sciences fund and finance. Accounted for the most numerous group respondents studying specialities: finance and accounting, management, banking and insurance: - 111 persons (34.7\%), $89(27.8 \%), 66(20.6 \%)$ 
and $45(14.1 \%)$. Among all responders the students achieved study portable exams - II . Including comprised - $221(69,1 \%)$ examined people, while the number of students studies and the represented 99 (30.9\%). In the examined group exceed slightly men $(51.3 \%)$. Most respondents were in the age 26-27 years and 24-25 years, sequentially $(25.6 \%$ and $22.2 \%$ ). They constitute the $47.8 \%$ of all examined patients. Least tested students were over the age of $30(8.8 \%)$ years, $20-21(12.5 \%)$ years as well as $28-29(13.8 \%)$.

\section{SUBJECTIVE ASSESSMENT OF THE STATUS OF THE KNOWLEDGE ECONOMY STUDENTS}

In the statement of the number of properly cast answers by students, it can be noted that all students answered the set of questions contained in the survey.

In the first instance students study desktop and portable exams I and II degree answered the question related to the subjective assessment of the knowledge economy financial, management and economics: Sampled answered the question: How Do and their general knowledge of economic, financial and management? Whether you're and knowledge is...? On the basis of the results obtained, students consider that their knowledge of economics, finance and life sciences management is at "strongly small" and "small" (the indicators in 2014 were until 52.3\% and 2016 - 51.5\%. In the further students have identified their state of knowledge at the level of the medium and in $2014-41.2 \%$ and in 2016 $-43.3 \%$. As can be seen in the period considered was decreasing interest test evaluators your knowledge economy as "strongly small" and "small", for these respondents who assess it as "medium". In addition, compared to the year 2014, of less than $3 \%$ decreased the number of assessors their knowledge as: "strongly high" and "high", for students evaluators it as "medium".

The next stage of research was related to the subjective assessment of the knowledge economy in selected slices demographic (place of residence and age), where students answered the question: How Do and its general knowledge of Economics, Finance and life sciences helpful? Whether you're and knowledge is...? .

By analysing the data from the Figure 3, students worse to assess the state of their knowledge, the respondents in age 20-21 years, residing in rural areas. In addition, compared to the year 2014, of less than $2 \%$ of the reduction in the number of respondents assessing their knowledge as: "strongly high" and "high", for respondents evaluators it as "medium". Students who declare that their knowledge is the medium level are over the age of 30 years and 28-29 years residing city from 100 to 500 thousand inhabitants. In relation to the year 2014, nearly $4 \%$, in both cases, decreased the number of test, evaluators their knowledge as "strongly small" and "small" for students showing it as "medium". At this point, it can be concluded that it is difficult to identify your students at age had a significant impact on the level of aid response, since respondents of different ages begin studies and work that is also a source of knowledge and awareness of economic.

Another question related to subjective assessment of knowledge, was to determine its in different areas: How do and the level of their knowledge and skills related to...? Whether you and knowledge is...? Whereas the area in which the students to assess the state of their knowledge, preferably to drop the ability to manage finances. Whereas the 


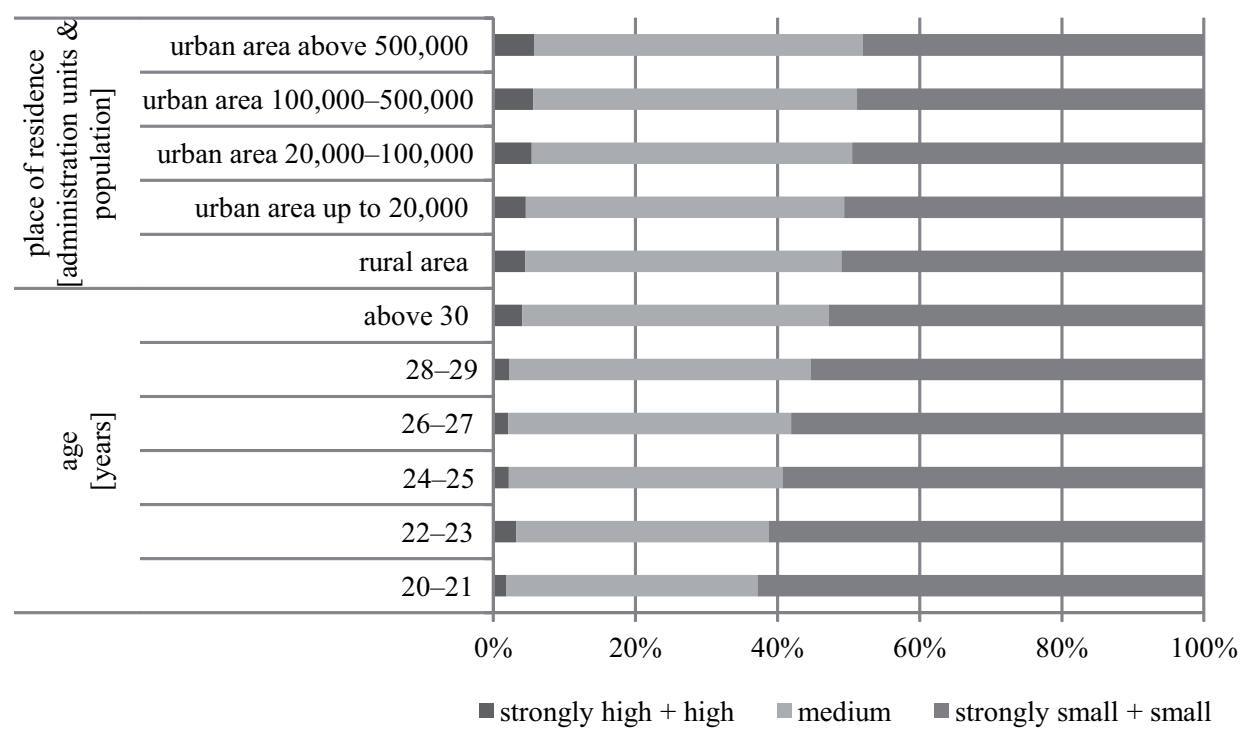

FIG. 3. How Do and its general knowledge of Economics, Finance and life sciences helpful? Whether your and knowledge is ...? (N 2016 = 320)

Source: the author.

year 2014 in virtually all areas of decreased interest students Evaluators their knowledge as "strongly high" and "high". While increased group those students who evaluate your knowledge as a "small" and "small". By analysing the above question, taking into account the degree and year of study, it can be stated that the stage of study does not determine the status of the knowledge economy students. Slightly higher level of knowledge have students and is in comparison with students II. Noteworthy is the fact that students starting process to study have a higher average from students finishing education (Table 1).

The next steps in the research were analysis of knowledge gaps and skills among women and men. Respondents had to answer the question: How do and the level of their knowledge and skills related to...? Whether you and knowledge is...? Both men and women the lowest evaluate your knowledge with the functioning of the commercial banks and the concept and essence of inflation. In the vast majority of areas women rate your level of knowledge of the lower than men. The biggest difference in subjective level of

TABLE 1 How do and the level of their knowledge and skills related to...? Whether you and knowledge is...? (N $2016=320)$

The average level of the knowledge economy

\begin{tabular}{|c|c|c|c|c|}
\hline \multicolumn{3}{|c|}{ The studies and the } & \multicolumn{2}{c|}{ Studio II } \\
\hline \multicolumn{3}{|c|}{$3.09 \%$} & \multicolumn{2}{c|}{$2.83 \%$} \\
\hline Year 1 & Year 2 & Year 3 & Year 1 & Year 2 \\
\hline 3.22 & 2,98 & 3.08 & 2.92 & 2.75 \\
\hline
\end{tabular}

Source: the author. 
knowledge between women and men is in areas: the functioning of the commercial banks, use of investments and deposits and pension rights. In virtually all areas there is less self-esteem women than men. Whereas the age of respondents, the largest gaps in knowledge, regardless of age, concern: insurance, concept and essence of inflation, pension and euro zone. The largest differences in subjective assessment of the level of knowledge between the newest and oldest age group, noted in the Euro Zone and pension benefits.

\section{OBJECTIVE ASSESSMENT OF THE STATUS OF THE KNOWLEDGE ECONOMY STUDENTS AT}

An objective assessment of the status of the knowledge economy students at was made on the basis of the results of the questionnaire as well developed indicators of the knowledge economy constructed on the basis of specific questions of management, of economics and finance ${ }^{3}$, relating inter alia to: ability to manage their own portfolio financial knowledge of the banking, insurance, pensions, rules save and invest, issues related to unemployment and inflation, the functioning of the zone and the euro currency, use of loans and credits, of non-cash transactions and the knowledge of the tax system.

Analysis of the test of the knowledge economy, i.e. response respondents on specific questions, showed that the knowledge students study desktop and portable exams I and II is much better than their subjective assessment. As can be seen from the above table, more than half of the valid questions has granted over $40 \%$ (strongly high, large), while over $21 \%$ of students replied to the medium level. Less than 6 correct answers has granted over $16 \%$, which gave strongly small' level of the knowledge economy. In comparison to the studies carried out in 2014 (the same questions), the percentage of students, which may be classified to the group of high, medium and low level of the knowledge economy, decreased slightly but does not give a significant statistical difference. One of the easiest questions for students has proved to be a question relating to manage their own financial resources. Just 51 respondents indicated an incorrect answer, which gives $15.9 \%$ of the total corresponding to this question. In the further minor problems meant question related to inflation - near $31 \%$ of students responded correctly. A similar result to the previous issues appeared the unemployment. 102 persons most often correct option, which gives $31.9 \%$ of the total corresponding to. Most problems with the reply have students with question regarding: the functioning of the zone and the euro (194 person $-60.6 \%)$, tax system (181 person $-56.6 \%)$, retirement benefits (169 person $-52.8 \%$ ) and insurance $(161-50,3 \%)$ all responders students (Table 2). Compared to the year 2014, increased interest of students, which comply with the correctly on almost all questions (for three questions, changes were significant). The largest increase (nearly 24 p.p.) for questions related to electronic money.

In view of the above data, it is difficult to clearly indicate that your age had an impact on the level of response. Students between 24-27 (8.2\%), the most appropriately correctly the entire survey and respondents aged 20-21 (18,5\%) - urgency, according to the lowest level of the knowledge economy. The results of that age range of 24-27 years,

\footnotetext{
${ }^{3}$ same questions were asked in an earlier edition of research, i.e.: years 2012 and 2014
} 
TABLE 2 Number of correct responses by the students I and II in selected slices demographic in $2016(\mathrm{~N}=320)$

\begin{tabular}{|c|c|c|c|c|c|c|}
\hline \multicolumn{7}{|c|}{ The number of correct answers } \\
\hline Sex & Strongly large and high & \multicolumn{2}{c|}{ Average } & Small and strongly small \\
\hline Women & 12 & $3.8 \%$ & 55 & $17.2 \%$ & 89 & $27.8 \%$ \\
\hline Men & 39 & $12.2 \%$ & 20 & $6.3 \%$ & 105 & $32.7 \%$ \\
\hline \multicolumn{7}{|c|}{ Age } \\
\hline $20-21$ years & 4 & $1.3 \%$ & 7 & $2.2 \%$ & 59 & $18.5 \%$ \\
\hline $22-23$ years & 9 & $2.8 \%$ & 11 & $3.3 \%$ & 36 & $11.3 \%$ \\
\hline $24-25$ years & 14 & $4.4 \%$ & 24 & $7.5 \%$ & 40 & $12.6 \%$ \\
\hline $26-27$ years & 12 & $3.8 \%$ & 11 & $3.3 \%$ & 27 & $8.4 \%$ \\
\hline $28-29$ years & 6 & $1.9 \%$ & 9 & $2.8 \%$ & 21 & $6.6 \%$ \\
\hline Above 30 years & 6 & $1.9 \%$ & 13 & $4.1 \%$ & 11 & $3.3 \%$ \\
\hline
\end{tabular}

Source: the Author.

reside in large cities, which confirms the results obtained with the evaluation studies of the subjective respondents.

The final stage in the study was to compare the subjective and objective assessment of the shortcomings of the knowledge economy among responders. Students consider have the least knowledge in the functioning of the zone and the euro currency, concept and essence of unemployment, inflation and knowledge of the banking sector. But if we examine the results of the test are we see that the least respondents evaluate: functioning zone and Euro currency, knowledge of the tax system. Relatively businessmen took counsel with questions about: knowledge of the insurance sector and rules on the functioning of the financial institutions and couple-Financial.

\section{CONCLUSIONS}

As a result of the studies carried out, has been implemented. The analysis of the level of the knowledge economy students at universities of the Świętokrzyskie enabled the verification that has been put at the outset article hypothesis. In the development has been confirmed hypothesis there is a relationship of the knowledge economy and the increase of awareness and competence of the younger generation in achieving financial stability and their independence. Following the above considerations, compared to the year 2014, although there were significant changes in the level of the knowledge economy test students. Still, over half of students has significant shortcomings in this area. Noticeable changes are in the following areas:

- The subjective assessment of the knowledge economy where decreased significantly interest assessments relating to knowledge "strongly high" and "high" for assessments medium,

- Subjective sense of knowledge is lower in 2016 in relation to 2014 (in virtually all areas is noted a statistically significant, 
The studies carried out, it was found that there were no significant between gender, age, the place of residence and economic knowledge students regardless whether he studies at the desktop and portable exams of the first and second degree.

\section{RECOMMENDATIONS}

Should enhance and improve the knowledge economy already at the level of the secondary education, but not only through theoretical knowledge but the introduction of practical lab, increasing the attractiveness of teaching, using existing sources of knowledge: Internet, broadcasts educational games, competitions, baler expertise that tasks practical (development projects). Encourage the young generation not only to raise the competence in the already existing areas but also to increase knowledge in new areas as confirmed by carried out surveys.

\section{REFERENCES}

CHŁOŃ-DOMIŃCZAK, KAWIŃSKI M., STAŃKO D., 2013. System oceny i prezentacji wyników inwestycyjnych kapitałowych systemów emerytalnych (The system of assessment and presentation of investment results of capital pension systems) [in Polish], SGH, Warszawa.

GRZEBIENIAK A., 2016. Ubezpieczenie pakietowe w sektorze mikro, małych i średnich przedsiębiorstw jako szansa na prowadzenie własnej działalności gospodarczej dla rozpoczynających (Package insurance in the sector of micro, small and medium enterprises as an opportunity to run your own business for beginners) [in Polish] (in:) J.W. Przybytniowski, A. Grzebieniak, S. Pieńkowska-Kamieniecka, (eds) Wybrane aspekty sektora ubezpieczeń i dodatkowego oszczędzania emerytalnego, Uniwersytet Warmińsko-Mazurski w Olsztynie, Olsztyn.

IWANICZ-DROZDOWSKA M., NOWAK K.A., 2011. Rola i znaczenie edukacji finansowej (The role and importance of financial education) [in Polish] (in:) M. Iwanicz-Drozdowska (ed.), Edukacja i świadomość finansowa. Doświadczenia i perspektywy, SGH, Warszawa.

JARIWALA H., SHARMA M., 2011. Financial Literacy: A Call for an Attention, Conference on Inclusive \& Sustainable Growth Role of Industry, Government and Society Conference Proceedings.

LABOUL A., 2012. National Strategies for Financial Education, Columbia-OECD-World Bank, Conference on Financial Education, 31 October, Cartagena.

LUSARDI A., MITCHELL O.S., CURTO V., 2010. Financial Literacy among the Young, Journal of Consumer Affairs 44(2), 358-380.

MESSY F.A., 2009. OECD Financial Education Principles and Best Practices, OECD-IOPS Mena Workshop on Pension Regulation and Supervision, February, retrived from www.iopsweb.org/principlesguidelines/42155019.pdf [accessed: 15.08.2017].

PACHOLARZ W.M., 2016. Pojęcie wiedzy w teorii ekonomii (The Concept of Knowledge in Economic Theory) [in Polish], Ekonomika i Organizacja Przedsiębiorstwa 8(799), 4-10.

PIEŃKOWSKA-KAMIENIECKA S., 2016. Świadomość i kompetencje finansowe osób młodych w kontekście percepcji dodatkowego oszczędzania emerytalnego (Awareness and financial competences of young people in the context of the perception of additional retirement 
savings) [in Polish] (in:) J.W. PrzybytniowskI, A. Grzebieniak, S. Pieńkowska-Kamieniecka, (eds.) Wybrane aspekty sektora ubezpieczeń i dodatkowego oszczędzania emerytalnego; Uniwersytet Warmińsko-Mazurski w Olsztynie, Olsztyn.

PRZYBYTNIOWSKI J.W., 2007. Edukacja ubezpieczeniowa i jej wpływ na świadomość ubezpieczeniową - wybrane problemy (Insurance education and its impact on insurance awareness - selected problems) [in Polish], Rozprawy ubezpieczeniowe 1(2), Rzecznik Ubezpieczonych, Warszawa, 111-119.

PRZYBYTNIOWSKI J.W., 2013. Konkurencyjność rynku usług pośrednictwa ubezpieczeniowego w Polsce (Competitiveness of the insurance brokerage services market in Poland) [in Polish], Wydawnictwo Menedżerskie PTM, Warszawa.

PRZYBYTNIOWSKI J.W., PACHOLARZ W.M., 2015. Knowledge management as a growth factor for the competitiveness of the insurance sector. Research your own, International Journal of Recent Scientific Research 6, 10, 1-9.

PRZYBYTNIOWSKI J.W., 2016. Współczesne funkcje i mechanizmy transmisji między sektorem ubezpieczeniowym a sferą realną gospodarki. Teoria i praktyka (Modern functions and mechanisms of transmission between the insurance sector and the real sphere of the economy. Theory and practice) [in Polish], CeDeWu, Warszawa.

The Importance of Financial Education, Policy Brief, 2006, OECD.

WILLIS L.E., 2008. Against Financial Literacy Education, Pennsylvania, retrived from http:// works. bepress.com/lauren_willis/1/ [accessed: 15.08.2017].

XU L., ZIA B., 2012. Financial Literacy around the World. Policy Research Working Paper 6107, The World Bank Development Research Group.

Summary. It has been found that the financial education increases substantially the economic knowledge to build awareness and competence of the younger generation and therefore the dissemination of this knowledge. The aim of this paper is to identify the importance of the knowledge economy in the growth of the build awareness and competence of the students in the management of finances in the current, constantly changing environment. Design development was subject to the hypothesis in accordance with that - there is a relationship of the knowledge economy and the increase of awareness and competence of the younger generation in achieving financial stability and their independence. This problem will be implemented using the analysis of the state of the knowledge economy university students of the Świętokrzyskie on individual economic areas. Method applied research area is anonymous questionnaire survey addressed directly using a survey to students study desktop and portable exams I and II degree.

Key words: economy knowledge, objective knowledge, economic awareness, subjective knowledge

JEL: D83, A2, A13

Corresponding author: Jarosław Wenancjusz Przybytniowski, Jan Kochanowski University in Kielce, Institute of Management, Poland, e-mail: j.w.przybytniowski@wp.pl

Received: 08.05.2017

Accepted: 12.05.2018 